\title{
THE IMAGE OF ELEKTRA IN ANCIENT GREEK TRAGEDY
}

\author{
Marta Heronovych \\ Master of Philology, Foreign Language Teacher, Lviv Secondary School № 30 \\ e-mail: martelita.88@gmail.com,orcid.org/0000-0001-6006-5728
}

\section{Summary}

The aim of this paper work is to find differences and similarities between three women who has the same name and tragedies were written in different times. These tragedies were like the first stage in the formation of the worldview of the Hellenic tragedy. It was necessary to pass three stages of development with certain modification and evolution of structural features of tragedies. In this study author sets the tasks: How does each of the three tragedies and women differ from each other? How did each of the previous stages differ from previous one as a new and higher step of its development? The conflict between man's aspirations and the need for reality leads us to recognize the dependence of a freedom and intelligent person to the will of the gods. We see the image of a desperate person in Euripides, Sophocles and Aeschylus. Due to the discoveries of these characters, we saw a new Greece.

Keywords: drama, destiny, performance, respect, freedom, genre of art, archaism, hero.

\section{DOI: https://doi.org/10.23856/3843}

\section{Introduction}

Researchers of the history of ancient literature have long been attracted by one of the most important problems of literary criticism - whether it is fair to consider the characters of Homer or characters of Greek drama. will or perhaps implied a moment of personal initiative in human action. Of particular importance in the study of this issue is the Greek tragedy. Although the controversy about the character in ancient Greek drama has a long history, it is still unclear what exactly covers the concept of character in Greek drama. character, or consider the characters of the drama only as symbols, types, allegories. In contrast, a number of scholars see in the characters of Greek drama sharply expressed individuality.

Of particular interest is the study of this issue based on the analysis of images of female heroes of the Greek tragedy, as from epic to tragedy significantly increased and expanded the role and function of women in fiction.

The urgency of the problem is, firstly, that the issue we are considering is of great importance for the history of not only ancient but also world literature in general position.

Third, the study of this issue on specific material will allow us to penetrate into the mechanism of individualization of the characters in the Greek tragedy, which is so important for addressing many crucial issues in the formation of world drama.

\section{The image of Electra in Sophocles}

The son of a wealthy Athenian gunsmith, Sophocles was an extremely enlightened man of his time, knew philosophy, music, which he composed for his tragedies, sang in a tragic chorus, participated in tragic competitions. He unconditionally believes in prophecy, dreams and gods, the notion that man cannot penetrate their highs thoughts combined in Sophocles with unshakable faith in man, his mental and moral powers, unlimited creative possibilities. Gods 
become for him such high concepts that he almost never brings them out in his tragedies, and they do not interfere in human affairs. mortals themselves often violate god-ordained traditions or laws and, unknowingly, take wrong steps, make mistakes, and thus cause misfortune.

Highly appreciating the human mind and freedom of action, Sophocles at the same time concludes that human capabilities are limited, because human destiny depends on higher forces, powerful and relentless. Happiness, according to the poet, is always short-lived: a person cannot be eternally happy.

Sophocles' contribution to the further development of the tragedy was significant. The poet completed the development of this genre of art, created an exemplary type of tragedy.

Sophocles deserves the credit for creating wonderful images of heroes who entered the treasury of world drama. These are already complex multifaceted images, deeply human, with a rich spiritual life. tragedy. This poet is considered the most outstanding master of her composition.Starting with the analysis of the tragedy of Sophocles "Electra", from the beginning we consider the central problem of the play. Sophocles increasingly turned typical tragedies into tragedies of characters, which, beyond the tragic factor, substitutes for the conflict of the soul, created a boundary between the characters of women.

We divide the development of the image of Electra into several stages. Our analysis is as follows:

1. Like the tragedy of "Antigone" and here special attention is paid to the performance of social traits of the character of the hero, such as:

Striving for revenge and motivating the need for revenge. position.

- Acceptance by the hero of the expected execution and preservation of the accepted

- Making a decision, finding an accomplice and maintaining the previous position, despite the absence of an accomplice.

2. Electra is similar to Antigone in a number of signs of character. Electra, as Antigone, makes decisions without hesitation, strict in relation to himself and others, confident in his rightness, fully aware of all the responsibilities of the decision. There is also a similarity between Antigone and Electra and in the female relationship regarding unrealizable marriage and unrealizable dreams.

3. Despite the similarity of these images, Electra still differs from Antigone, revealing such traits that are inherent in the hero-fighter. This can be seen in the following lines:

(Egisf: Ah, death has come! Please let me say a word!

Electra: For God's sake, my brother,

Don't let him continue his life with words,

What good is it for us to hate a thief

Will death delay?

Now kill, the body is killed

Give the gravediggers worthy,

From our point of view further, before

The pain of the tormented soul will not subside.) (Zofja Schulbaumowna, 1952).

For example, Electra has a sense of gratitude to those who sympathize with her, although she is obstinate to her sister, but gives her advice, guides her, optimistic about the return of Orestes. This feature is not observed in the nature of Antigone.

4. Various emotional states of Electra.

Sophocles painted in the image of Electra an extremely rich range of emotions. It is especially necessary to mention a worthy contrast change of emotional reactions of Electra. 
5. Electra, as the tragedy progresses, gradually shows more and more sarcasm. At the last stage, she is mocking, ruthless, able to seduce to achieve the goal, and does not doubt her rightness.

him, did you feel sorry for his father? (Clytemnestra's voice: Child, my child! Mother pity! Elektra: Did you feel sorry for

Clytemnestra's voice: You hit!

Electra: if you are strong, then again!) (Tronsky, 1983).

All this should indicate the exceptionally great importance that the individual characterization of the hero had for Sophocles. At a later stage of his career, Sophocles began to show great interest in the character, as evidenced by Plutarch's report that "Sophocles' style has changed, he has become more an expression of character and the best." (Kvirikashvili, 1982).

In our opinion, the main purpose of Sophocles' tragedy is to show the artistic image of Elektra against the background of her mother's murder, although the perpetrator of the act is not the main heroine of the tragedy, but her brother Orestes.

In the study of universal motives of world literature, the image of Electra, as a rule, is considered within the motive of revenge. Although this approach can be considered legitimate from the point of view of the plot, we think that when dealing with specific dramatic works, we must make the appropriate clarification. Already in "Hoefor" along with the motive of revenge, there was a "tyranny" of Clytemnestra and Aegis. In Sophocles, this moment is even more profound and along with the moment of revenge shows the nature of those against whom revenge is directed.

Electra is inherently grateful to those who sympathize with her, ashamed of excessive feelings, although she is strict with her sister, but gives her advice, guides her, optimistic about the return of Orestes.Electra is presented as a good sign of the human breed, smart, prudent: it can be misleading, it can seduce, if necessary to achieve the goal. Sometimes she is mocking, ruthless, unrestrained in expressing emotions.

Greek woman, especially Athenian, did not play a major role in public life: locked in gynecology was to be a good woman and mother. Along with all these images becomes Elektra-avenger, the initiator of the terrible act of maternal murder, although Orestes is its executor, Elektra's character was extremely difficult to imagine and the hero thought to remove unsympathetic traits, in the position of the then even unnatural and repulsive.

However, we can see here the profound truth through which Sophocles sought to psychologically deepen the figure, revealing why there is one and not another. The heroine characterizes herself in monologues and dialogues with Clytemnestra and the choir, and so we can find out what Electra could be and what she became.

Electra experienced a terrible tragedy in her youth: the betrayal of her mother and the death of her beloved father the minute he returned home after a long absence.

It is easy to imagine the oppression with which the girl - abandoned by her mother, who gave all her love to her eldest daughter - as a child she was forced to take care of her younger brother, she was waiting for the arrival of her father-hero, the leader of the glorious campaign, as she thought that after his return everything would change for the better. Hope summed up: Electra really saw her father, but only to lose him a second time and forever and in the young memory of the child killed a disgusting picture of murder. The royal daughter knows that she must take revenge for such a concession, it is her only thought and only desire since then. But this revenge must be done on her own mother! Does the daughter who so many years after her father's death mourns him so much in the gutter, if yesterday she saw his noble head cut off with an ax, there is not the slightest sympathy for his mother? We see this in the lines: 
(Electra: And you are already shouting: he is like my daughter

Respects my mother!. You are the owner for me

Cruel, not mother: the burden is heavy

Changed, in agony all my life-

Both you and the one with whom you share your father's bed!) (Taras Shevchenko Institute of Literature of the National Academy of Sciences of Ukraine, 2006).

Electra herself feels that her hatred for her mother is something ugly, terrible, fills her with painful shame (she talks about it when in it, I throw justice against my mother), but it is the fault of the "inhuman mother" who persecutes her at every step, humiliates, ridicules, lies, threatens together with the hated stepfather Egisph. Princess Electra wears rags, her hair is tangled, her face is pale and helpless, feeds on, eaters from the lord's table and sleeps on a hard bed, has no hope of getting married and is doomed to die infertile, and then does not fulfill the obligations of a Greek woman ... Electra is deeply moved and it is connected with the sense of duty, the obligation to the deceased father make it sensitive and firm at the same time (long-term patience is not always made noble, only numb to patience), as far as her mother was concerned, so far away at the moment of her death, she decided on "the most terrible event in the Greek tragedy," such as we cannot forgive her: "Push again!" But, however, if the girl-sensual, how naive and femininely frivolous in the exaltation of mercy and joy can be that gloomy Electra in relation to her brother Orestes! She loves him as her master and head of the family, as a brother and son, because she nursed, caressed and kissed him in her arms as a deliverer, an unexpected leap from the highest despair and mourning (cry over the true ashes of Orestes) to the joyful triumph and memory, the rapturous delight is truly feminine: and Electra, who has so far devised a murderous plan, now does not think that the danger in general has not passed, that her loud outburst of feelings can destroy both her and her brother, only wants to hug and kiss the miracle of the find all the time, she wants to enjoy, to delay a happy moment, the thought of revenge disappears, only boundless sisterly love remains. The image of Elektra complements the gallery of brilliant images of Sophocles, who was the first among Greek playwrights to try to reveal more deeply the inner world of an independent woman.

\section{The image of Elektra in Aeschylus}

The "father of tragedy", as he was called by ancient Greek scholars, was Aeschylus. The poet was born at the end of a turbulent period that radically changed the socio-political life of many cities in Greece. Witness, and sometimes a direct participant in the events of the first half of the $\mathrm{V}$ century BC,Aeschylus repeatedly used the problems they created in their tragedies. Aeschylus enjoyed considerable popularity, as evidenced by his 13 victories in dramatic competitions.

He lived in a time when the ancient traditions of tribal society were still evident and continued to affect the minds of citizens. This explains the complexity of the poet's worldview, which to some extent was associated with the old ideology of the aristocracy, but at the same time understood the superiority of democracy. Belief in the gods is closely combined in Aeschylus with the idea of the inviolability of the law of justice, which is subject to both the individual and the family and the whole nation. Violation of this moral truth leads to inevitable punishment. The problem of truth, the obligatory punishment of the criminal for shed blood, the problem of tribal revenge and the curse that weighs on the family, which develops Aeschylus in his tragedies, are always inextricably linked with real political circumstances or events. It is no coincidence that F. Engels called him a "pronounced tendentious poet", as a poet who pursued 
in his works some well-defined political idea, tendency. In the only tragic trilogy "Oresteia" that has come down to us, Aeschylus develops the problem of the tragic fate of the Pelopid family. But in each part of the trilogy there are very specific political motives.

However, in general, Aeschylus made a huge contribution to the development of tragedy, turning it into an important social genre of art, a paramount means of ideological influence on fellow citizens.

His tragedy is much more complicated, it is characterized by a monumental and pathetic style, titanism, generated by the powerful rise of the Athenian state.

Aeschylus introduces for the first time techniques that have become the property of modern drama. In particular, he was the first to use the formula of tragic silence, the songs of the choir in his tragedies often create an atmosphere of horror on stage, that is, the expectation of something terrible and inevitable. The poet began to use techniques of contrast, tragic irony. He skillfully used prophecies and divination, the means by which the crime was committed, to create again and again an atmosphere of tension on stage, to cause horror in the audience. His language is full of archaisms and innovations, epic comparisons, poetic epithets, vivid metaphors, inner rhymes and assonances.

In addition, it is believed that Aeschylus first introduced in the theater scenery, painted masks expressing the tragic moods of man, as well as koturny.

As a result of the analysis of the image of Electra, we come to the following conclusions: "Hoefora" of Aeschylus represent a significant stage in the process of dramatic interpretation of the image of Electra. Aeschylus may have been the first author to introduce Electra so intensely into the tragedy and to try to give a separate individuality to its image. The playwright pays attention to those strokes of the character of the hero, which are manifested in individual episodes. For example, Electra is God-fearing, she is characterized by doubts, she hesitates to make a decision (at the first stage of her actions directs the choir);it is also characterized by shyness, hesitation, it is not easy to convince her of something. This can be seen in the following lines:

(Orestes: Orestes called, I know, with pain, with tenderness.

Electra: My hopes have come true?

Orestes: I'm here. Don't look for another lover.

Electra: You are a stranger to me. I thought of deceiving me.

Orestes: Yes, so I'm cunning with myself.

Electra: Do you want to laugh at my dinner?

Orestes: Then over yours too.

Electra: Yes, you-Orest! I'm talking to you, with you?) (Chistyakova, 1959).

Electra loves her brother too much. We can talk about the emotional reactions of Electra: she is alarmed at the sight of curls of hair, and before she recognizes her brother, in her soul there is a continuous struggle between hope and suspicion, she is infinitely happy to meet Orestes. An attempt at self-esteem is also noted on her part. Electra in the first scene calls herself inexperienced, in a coma she says that she has a cruel soul, like a wild lioness. However, despite all this, its character is still not integral. The positions which are shown by Electra in various episodes, are in appreciable contradiction with each other. We can say that the painted in the original scene Electra (defenseless, dependent on the chorus) is very different from the praying Electra, telling in detail the reasons for his hatred (the arrogance of the murderers, his position, the expulsion of Orestes). Electra in the coma becomes even more independent in front of us, when she herself encourages Orestes, who was respected in his decision to kill his mother. Of course, all this could be explained, to allow the development of the hero's character in the tragedy, however, we think that the contrast between the Electra of the original scene 
and Electra, actively involved in the action, is so sharp that it can not be explained by simple character development. All this, in our opinion, confirms the fact that Aeschylus is not painted a whole, consistent character. What explains this is difficult to say: the imperfection of the technique of creating characters or the specificity of the principles of Aeschylus. One thing is clear: Aeschylus created the image of Electra, but failed to create a character that could be considered a complete character.

However, in general, Aeschylus made a huge contribution to the development of tragedy, turning it into an important social genre of art, a paramount means of ideological influence on fellow citizens. His tragedy is much more complicated, it is characterized by a monumental and pathetic style, titanism, generated by the powerful rise of the Athenian state. Aeschylus introduces for the first time techniques that have become the property of modern drama. In particular, he was the first to use the formula of tragic silence, the songs of the choir in his tragedies often create an atmosphere of horror on stage, that is, the expectation of something terrible and inevitable.

The poet began to use techniques of contrast, tragic irony. He skillfully used prophecies and divination, the means by which the crime was committed, to create again and again an atmosphere of tension on stage, to cause horror in the audience. His language is full of archaisms and innovations, epic comparisons, poetic epithets, vivid metaphors, inner rhymes and assonances. In addition, it is believed that Aeschylus first introduced in the theater scenery, painted masks expressing the tragic moods of man, as well as koturny.

\section{The image of Electra in Euripides}

The last of the prominent Greek tragic poets, Euripides became a poet during the crisis of the Athenian slave-owning democracy. The biography of Euripides is almost unknown to us, and the data that have come down to us are quite contradictory and abound in the inventions of his contemporaries, who did not like him very much. It is also known that the poet never took an active part in the political and social life of his native polis, did not communicate with anyone in particular. But he argued that he best served his country with his tragic works.

A subtle and insightful observer of the reality of his time, Euripides saw and understood well the processes that accompanied the discord of the Athenian slave-owning state. And the symptoms of her incurable disease became more and more apparent: class contradictions grew among the citizens of the polis; from, there was usury generated by trade relations, which gradually destroyed the small craft. Euripides not only noted all these tendencies for himself, but also transferred them to his works. To reflect these processes, Euripides changed to some extent the nature of the tragedy itself, both in content and form. It is no wonder that he is considered not only a successor but also an outstanding reformer of the traditional Hellenic tragedy.

Euripides focuses on the family and domestic conflicts of his heroes. His tragedy takes the form of a family and domestic drama, which almost does not affect the broad problems of socio-political nature. And if they even appear, they are solved in a narrow circle of family life. The problems posed by Euripides, to some extent contradicted the then prevailing ideology. The poet repeatedly emphasizes in his works the need to give women greater rights. The poet became the creator of female images, which the tragedy did not know before him. In them he emphasizes nobility, tenderness of soul, female pride, his quiet and submissive heroines suddenly turn out to be extremely strong, strong-willed and devoted natures. Euripides often changed the form of his tragedies. Along with works that were built on traditional models, he also owned those that no longer fall under the definition of this genre. In Euripides, there is 
already an intrigue, comic scenes are introduced, which caused a smile in the citizens, and there is a happy ending. It was a qualitatively new dramatic genre, although at that time it did not receive a certain name (only in modern times will the name of tragicomedy, domestic drama).

What was new in Euripides' tragedies was that he already portrayed his heroes "as they are." Despite the mythological names, ordinary people appeared before the audience, who often carried the characteristic features of the crisis period of the polis system. Boldly using, in accordance with the ideological ideas, mythological plots, the poet at the same time criticizes them. Following the path of degeneration of the characters, Euripides uses purely technical techniques, so his characters, if circumstances so require, are often dressed in rags. Depicting their terrible sufferings, the poet leads the viewer to the conclusion that it is impossible to justify these sufferings by any increase in the higher justice of the gods. The confusing action at the end of a tragedy is often resolved with the help of a deity who soars from above and tells the truth. The role of the choir is completely reduced, the parts of which turn into a kind of divertissement, the language of the heroes becomes simple.

Euripides in his tragedies often changes the old myths, leaving them only the names of the heroes. Using mythological plots, the great tragedian expresses in them the thoughts and feelings of his contemporaries, raises topical issues of his time. He, so to speak, modernizes the myth. And this is one of the most important features that distinguishes Euripides from Aeschylus and Sophocles. The difference in the artistic system of playwrights is especially noticeable when comparing the tragedy of Euripides "Electra" with the tragedy of the same name by Sophocles and with the tragedy of Aeschylus "Hoephora", which is the second part of his trilogy "Oresteia".

In considering the artistic image of Electra in the tragedy of Euripides, we pay attention to Euripides' interpretation of the question of the murder of his mother, the discussion of the image of Electra in Euripides.

We consider the development of the artistic image of Elektra Euripides at several stages and as a result of the analysis we come to the following conclusions. Here, as in the case of Medea, it is not possible to fully identify the strokes of the general plan, because in the motivation of the actions of Electra is particularly pronounced personal element. Euripides achieves an extraordinary strengthening of the personal motive of revenge by promoting the so-called "selfish" moment in the image of Electra. Electra is constantly complaining about her fate, she is even more interested in it than her brother's return and revenge. Drawing its position, it significantly thickens the paint. This stroke is almost at every stage is the guiding action of Electra.

It should be noted that the second features of the character of Electra seem to be naturally associated with this basic property. For example, Electra is hysterical, suspicious, difficult to convince, she is mocking, hates her mother, devoid of positive emotions. We can see this in the following lines:

(Orestes: I rightly touched your hand.

Electra: Why a sword? An ambush for what?

Orestes: Oh, don't run, I'll tell you and you'll believe it right away.

Electra: And so I stand when I can’t escape by force.) (Yarkho, 1958).

In the nature of Electra there are features of the second type, which should also be noted: Electra is grateful to the man who did not desecrate her bed, as can be seen from the following lines of her dialogue with her brother:

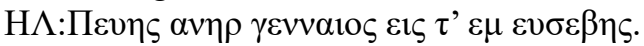

$\mathrm{OP}: \mathrm{H} \delta^{\prime} \varepsilon v \sigma \varepsilon \beta \varepsilon 1 \alpha \tau \imath \varsigma \pi \rho \circ \sigma \varepsilon \sigma \tau 1 \sigma \omega \pi \mathrm{\sigma} \sigma \varepsilon \varepsilon$;

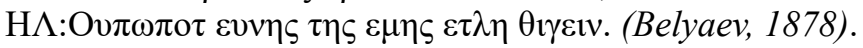


(Electra: Poor and honest and he respects me.

Orestes: What is that respect?

Electra: He has never touched me before.) (Weissman, 1991).

She also loves her brother and is faithful to him, takes full responsibility for the murder of her mother, falls into despair. However, these small positive signs do not affect the general idea left by the image of Elektra. Personal motivation in the tragedy is enhanced by the fact that Clytemnestra and Aegisph in the interpretation of Euripides are less tyrannical than the same characters in Sophocles. Thus, the revenge performed by Orestes and Electra, in the tragedy of Euripides is invisible to the extent of personal motives revenge.

\section{Conclusions}

At the end of the work it is necessary to present a generalized picture of the comparative analysis of the proposed images. To this end, we have primarily identified those qualities that are somehow present in all the images we studied and that characterize them as heroes who do not obey the situation, struggling to achieve the goal. These properties are the essence of the following: resilience, impatience with inaction, the desire to achieve the goal (with or without an accomplice), uncompromising. Now it is necessary to specify all those features which are shown in characteristic characters in parallel with the above-stated and which serve for even more accurate depiction of individuality of heroes. We have divided these properties into different semantic groups (disobedience and stubbornness, confidence and insecurity, analyticalness, ability to use all available means to achieve the goal, humanity and inhumanity, attitude to others, wisdom, ability to control feelings and emotions, etc.). This list convinces us how different areas of human, personal qualities can reflect these strokes. The list shows how the strokes of different groups are implemented in each of the characters we study. Given the results of the above analysis, we can draw the following conclusions:

Each of the heroes we have considered needs an individual approach, as both the number and intensity of the characteristic features of these characters are different. Different images, even in the work of one playwright differ from each other not only in the logic of the plot, but also in character traits. Aeschylus, Sophocles and Euripides differ not only in the concept of the hero, but also the principles of creating an artistic image. In the case of the hero of Aeschylus studied by us, individual touches do not create a single complete system, and it is worth noting the inconsistency in the image of the hero in different scenes. Sophocles depicts the properties of both the so-called generalized character and the individual and characteristic features of these heroes, who belong to different groups, serve to more comprehensively illuminate a single image. In the protagonists of Euripides, the emphasis of the character is shifted mainly to individual traits.

In Aeschylus, Orestes realizes the inevitability of killing his own mother only as a result of long reflection. While reflecting on this question, there is a tireless pressure from Elektra and the choir, and this action itself is a new link in a number of contradictions, which are the meaning of "Oresteia".

Euripides has removed any halo of heroic deed from his mother's murder, and his brother and sister feel depressed and broken after it is performed.

In Sophocles, Electra feels not only the slightest doubt in the expediency of revenge, but also in the justice of his action. Accordingly, she feels no more than an executor of a divine command, and she is concerned only with the preparation and unimpeded execution of the will of the gods. 
Our study proves that the images of Electra in Aeschylus, Sophocles and Euripides differ significantly from each other in that some of them are more, some less represented, and some do not present the characteristic features of a particular group. Accordingly, the sums of characteristic strokes that determine the individuality of the heroes of tragedies also differ significantly.

The artistic image of Elektra in Euripides considered by us is exclusively multifaceted at the level of individual strokes. If in the images of some other characters of Euripides is difficult to single out any one specific stroke on the principle of the dominant property, then in the image of Electra such a pronounced selfishness can undoubtedly be considered as such. This trend, obviously, should indicate a process that took place in ancient Greek literature and was aimed at highlighting the dominant character in literary heroes.

The variety of strokes we have singled out at the individual level is a consequence of the undoubted interest of Greek playwrights not only in what their characters experience, with what tragic conflicts they are connected, how they act, but also in who they are, how different individuals are these heroes. Thus, playwrights were interested in the characters of their characters.

In conclusion, it should be noted that despite the limited rights of women in ancient Greece, their images are actively present in the Greek tragedy.

\section{References}

Zofja Schulbaumowna, “Kobiety w tragedjach Sophoklesa”, W., 1952.

Tronsky I.M., (1983) Istoria antichnoi literatury [History of ancient literature], Moscow: Higher School [in Russian]

Kvirikashvili L.S., (1982) K hlavnoi probleme trahedii "Elektra" Sofokla i Evripida [To the main problem of the tragedies of" Electra "of Sophocles and Euripides.] - Conference of young scientists of the Caucasus. Abstracts, Batumi [in Russian]

Taras Shevchenko Institute of Literature of the National Academy of Sciences of Ukraine,(2006) Davnohrecka tragedia: Eshil, Sofokl, Euripid [Ancient Greek Tragedy: Aeschylus, Sophocles, Euripides], Kharkiv [in Ukrainian]

Chistyakova N.A., (1959) K voprosu ob obrazah trahicheskih heroev v dramah Sofokla [To the question of the images of tragic heroes in the dramas of Sophocles." - Collection: "Classical Philology], Moscow [in Russian]

Yarkho V.N., (1958) Eshil [Aeschylus], Moscow [in Russian]

Belyaev D.F., (1878) K voprosu o mirovozrenii Euripida [To the question of the worldview of Euripides], Kazan [in Russian]

Weissman A.D., (1991) Drevnehrecheskii slovar [Ancient Greek Dictionary], Moscow [in Russian-Greek]

Maletska A., Landovsky Z., (2002) Polsko-Ukrainskii slovnyk [Polish-Ukrainian Dictionary], Kyiv [in Ukrainian-Polish] 